\title{
ANTARCTIC VIGNETTES VII: THE SEARCH FOR S. TASMAN - POSTSCRIPT
}

\author{
by Herbert J. G. Dartnall
}

(with three plates)

Dartnall, H. J. G. 2013(17:xii): Antarctic Vignettes VII: The search for S. Tasman - postscript. Papers and Proceedings of the Royal Society of Tasmania 147: 11-13. https://doi.org/10.26749/rstpp.147.11 ISSN 0080-4703. Department of Biological Sciences, Macquarie University, New South Wales 2109, Australia. E-mail: herbdartnall@pip.com.au

Tasman Spaulding served as an Able Seaman on the S.Y. Terra Nova on the 1903-1904 voyage to Antarctica. A clerical error that reversed his given and family names meant he never knew of the bronze Polar Medal awarded for his services on the expedition. For the last 108 years the incorrectly named medal has languished in the archives of the Royal Mint in the United Kingdom but has been released for display at the Tasmanian Museum and Art Gallery in Hobart.

Key Words: Tasman Spaulding, S. Tasman, S.Y. Terra Nova, Polar Medal in bronze.

\section{BACKGROUND}

The Terra Nova arrived in Hobart on 31 October 1903. She had been sent by the Lords of the Admiralty under the command of Harry McKay with instructions to proceed to the Antarctic and rescue Captain Scott. Captain McKay was to extract Scott's ship, HMS Discovery, from the ice or, if that proved impossible, to abandon her and return home with Captain Scott and his men (Scott 1905, Savours 1992).

Captain Scott's failure to send the research ship HMS Discovery back to Lyttelton as planned at the end of March 1903 had incurred the displeasure of the Lords of the Admiralty (Aldridge 1999). Charged with mounting a relief expedition the Admiralty bought the steam-powered wooden barque the Terra Nova from C.T. Bowring and Company Ltd of Liverpool for $£ 20,000$ and had her speedily re-rigged and made shipshape in Dundee (Jones 1973) and appointed Harry McKay her Master. McKay was probably the most experience ice-master and navigator then serving with the Arctic Whaling Fleet (Aldridge 1999).

Captain McKay assembled a crew of Dundee whalermen many of whom had served with him before. They were experienced seamen, hard men, many with a fondness for whisky (Jones 1973). The relief voyage was to be a dry one, and they might be away for several years so it is unsurprising that many turned up blind drunk when they were due to set sail. In the confusion one man, William Luke Ryan, went overboard and drowned whilst the ship was in the River Tay, while James Anderson immediately deserted. The Terra Nova had already sailed when he was caught and he was taken by the Royal Navy, under guard, to Aden where he was reunited with the Terra Nova.

The Terra Nova set sail on 21 August 1903 and arrived in Hobart 17 days ahead of schedule thanks to three Royal Navy ships that towed the ship at speed to a point just east of the Horn of Africa. HMS Minerva towed the Terra Nova from Portland to Gibraltar; HMS Vindictive towed through the Mediterranean with HMS Fox completing the section from Port Said down into the Indian Ocean (Jones 1973). After the tow was cast-off the Terra Nova made her own way to Hobart where she then spent the next five weeks, undergoing repairs, coaling and generally preparing for the voyage south.

Meanwhile many of the Terra Nova's crew had a riotous time in Hobart. Nine sailors, at some time during their stay, went absent without leave, a relatively minor indiscretion, but two of these men compounded the offence by assaulting the police and were given custodial sentences of three and four months (BT100/50). Captain McKay discharged the major trouble maker, George Mitchell, but was now one seaman short. Just then Tasman James Spaulding, a local lad, was on the Hobart waterfront looking for a job (BT 100/50). At 23 he was an experienced seaman having rounded Cape Horn in square-riggers and he was quickly recruited (pl. 1). Six days later on 6 December 1903 the

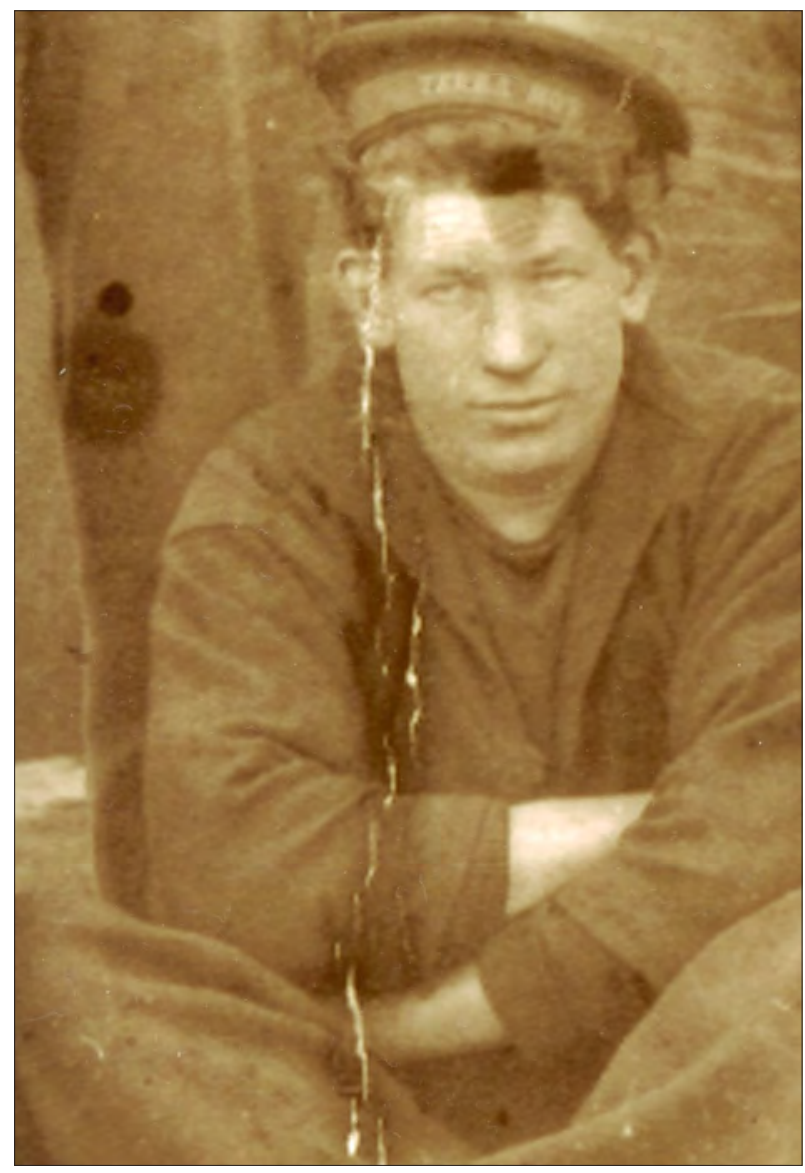

PLATE 1

Tasman Spaulding A.B. on the Terra Nova. 


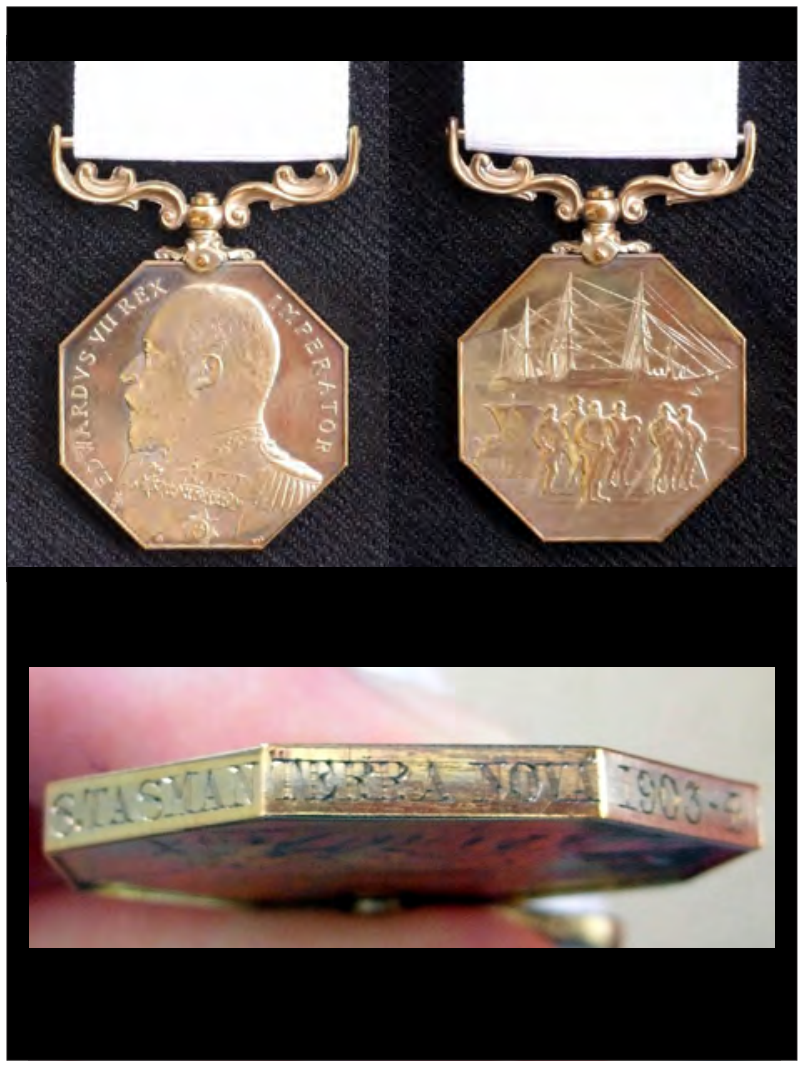

PLATE 2

Tasman Spaulding's bronze Polar Medal. The image top left shows the medal's obverse. The image top right shows the medal's reverse; while the image at the bottom shows the naming round the edge of Tasman Spaulding's Polar Medal.

SY Morning and the Terra Nova with Tasman Spaulding on board set sail. The two ships made good progress with the Terra Nova, the more powerful, invariably leading the way. When they arrived off Hut Point on 5 January 1904 nearly 20 miles $(32 \mathrm{~km})$ of solid pack-ice blocked their passage to HMS Discovery compared with the just 5 miles $(8 \mathrm{~km})$ that the Morning's captain, Captain Colbeck had reported the previous March (Aldridge 1999). Over the next seven weeks the crews of the three ships nibbled away at the pack-ice. They cut channels with ice saws, and blasted the ice with charges of gun cotton while Captain McKay aboard the Terra Nova continually rammed the ice head-on. Progress was slow and right until the last possible moment it appeared that they would have to abandon the Discovery when a series of great ocean swells carried the last of the ice away and the Discovery was at last free.

The three ships then made their own way back to the United Kingdom via New Zealand. Tasman Spaulding disembarked at Lyttelton. On Captain Scott's return to the United Kingdom authority to grant the award of a medal akin to the Arctic Medals of 1818-1855 and 1875-1876 was sought. This was duly granted on 14 September 1904 when the Polar Medal came in to being. Generally it was awarded in silver with a clasp inscribed ANTARCTIC 1902-04 to the officers, scientists and crew of HMS Discovery; and in bronze without a clasp, but with the years of service inscribed round the edge after the naming, to the officers and crew of the two relief ships (ADM 1/7848; Poulsom \& Myres 2000).

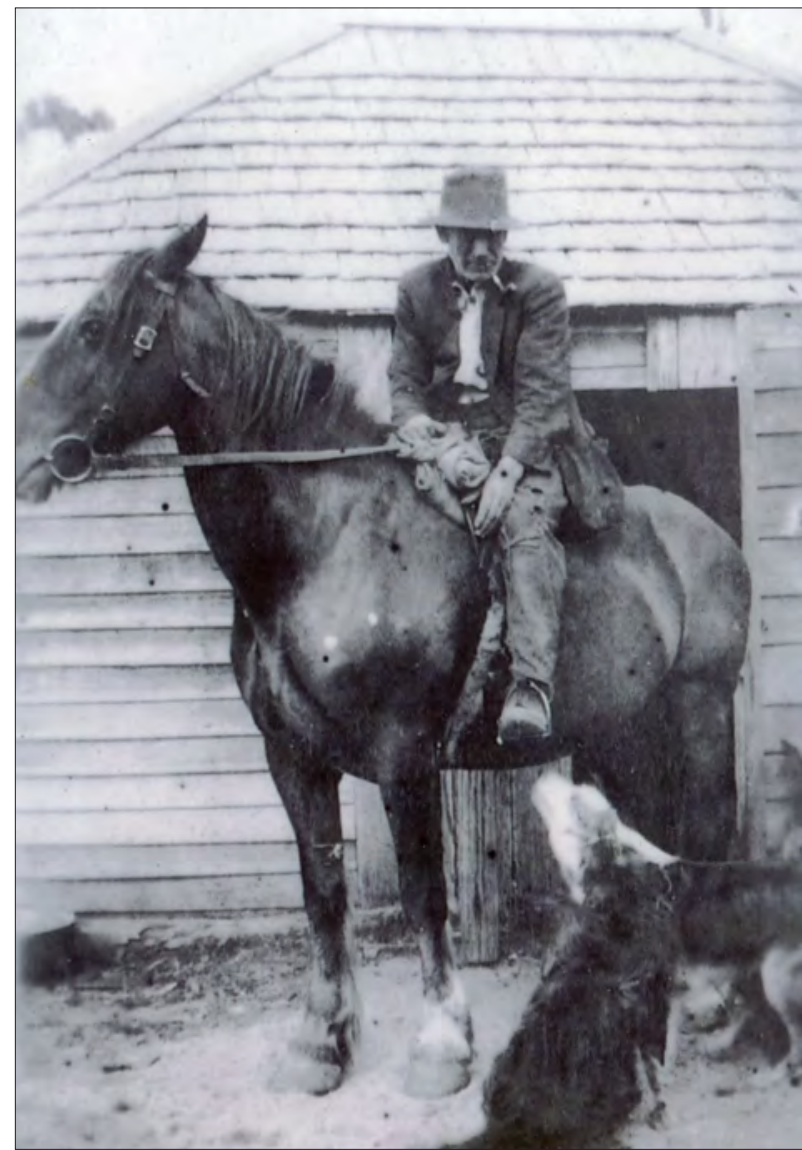

PLATE 3

Tasman Spaulding on the farm in later life.

\section{TASMAN SPAULDING'S STORY}

Thus Tasman Spaulding was awarded the King's Polar Medal in bronze (pl. 2) together with the rest of the Terra Nova's officers and crew whose work during the expedition was deemed satisfactory (ADM 171/61). Most of the medals to the men of the Terra Nova were presented by the Lord Provost, Dundee at a ceremony on 28 November 1906. Tasman Spaulding was of course living in Tasmania and his medal should have been posted to him. Unfortunately, despite clearly signing his name as Tasman Spaulding several times in the ship's $\log$ (BT 100/50) at some stage in the medal naming process Tasman Spaulding's given and family names were reversed and his medal was inscribed S. TASMAN "TERRA NOVA" 1903-4 instead of T. SPAULDING "TERRA NOVA" 1903-4 (pl. 2). Consequently when it came to send his medal, no one of the name S. Tasman could be found and the medal went unissued. Tasman Spaulding never learnt of his award. He married his childhood sweetheart in 1913 and settled down to a fishing and farming life style (pl. 3) in southeast Tasmania and died there in 1939 (Dartnall 2008).

\section{TASMAN SPAULDING'S POLAR MEDAL}

I have been interested in the men who took part in Antarctic Expeditions for a number of years and have visited Hobart several times in the course of my research. On one of these visits I decided to check Tasman Spaulding. He was of 
particular interest as I believe he was the first Australianborn Australian to receive a Polar Medal. His birth, death and marriage records indicated that he had lived all his life in Dunalley (Dartnall 2008). On a subsequent visit to that hamlet I met up with Bill Dunbabin who as a boy had lived next door to Tasman Spaulding and his wife. Bill introduced me to George Whitehouse and Jim Spaulding - two of Tasman Spaulding's nephews - and my interviews of these three gentlemen formed the basis of my earlier paper on Tasman Spaulding (Dartnall 2008). Following the publication of that paper Rear Admiral J.A.L. Myres, C.B., then Secretary of the United Kingdom Polar Medal Assessment Committee took up the case. Admiral Myres confirmed the medal had never been issued and ascertained that since naming it had remained in the Royal Mint's archives. Enquiries were made and permission was granted for the medal to be made available. Sadly none of Tasman Spaulding's children lived more than a couple of months and he has no direct descendants. His Polar Medal has therefore been secured for display at the Tasmanian Museum and Art Gallery (TMAG) on a long term loan. The medal was presented to Sir Guy Green A.C., K.B.E., C.V.O., Chairman of the Board of Trustees and The Royal Society of Tasmania's nominee, on 20 June 2013 in the Islands to Ice Gallery TMAG where hopefully it will soon be on permanent display.

\section{ACKNOWLEDGEMENTS}

Thanks to Jim Spaulding and George Whitehouse for the biographical information and photographs of Tasman Spaulding and to Rear Admiral J.A.L. Myres C.B. and Captain S. Lawrence M.B.E., R.D. for securing the loan of the Polar Medal to the Tasmanian Museum and Art Gallery.

\section{REFERENCES}

ADM 1/7848: Admiralty file held at the National Archives Kew, London.

ADM 171/61: Admiralty file held at the National Archives Kew, London.

Aldridge, D. 1999: The Rescue of Captain Scott. Tuckwell Press Scotland: 215pp.

BT 100/50: Board of Trade file held at the National Archives Kew, London.

Dartnall, H.J.G. 2008: Antarctic Vignettes II: The search for S. Tasman, AB on the Terra Nova, 1903-04. Papers and Proceedings of the Royal Society of Tasmania. 142(2): 47-48.

Jones, A.G.E. 1973: Harry Mackay, Master of the Terra Nova. Antarctica 6(9): 316-321.

Poulsom, N.W. \& Myres J.A.L. 2000: British Polar Exploration and Research 1818-1999. Savannah Publications: 729pp.

Savours, A. 1992: The Voyages of the Discovery: the illustrated history of Scott's ship. Virgin Books: 384pp

Scott, R.F. 1905: The Voyage of the Discovery'. Vols $1 \& 2$. Smith Elder \& Co., London: 556 \& 508pp.

(accepted 1 October 2013) 
